\title{
Apresentação ao Dossiê
}

\section{História dos Serviços Públicos}

\author{
Fabiano Quadros Rückert \\ Universidade Federal do Mato Grosso do Sul (UFMS) \\ José Carlos da Silva Cardozo \\ Universidade Federal do Rio Grande (FURG) \\ Organizadores
}

No final do ano de 2016 a Revista Brasileira de História \& Ciências Sociais definiu como tema para o dossiê referente ao segundo semestre de 2017 a História dos Serviços Públicos. No texto usado para divulgar a chamada de trabalhos afirmamos que "temas como a intervenção do governo na economia, a saúde pública, a promoção da educação básica e superior, o funcionamento da justiça e da assistência social são frequentes na agenda de pesquisadores de diferentes áreas"; no entanto, apesar do interesse da História e das Ciências Sociais pela organização e funcionamento das instituições públicas, "os estudos focados especificamente na historicidade dos Serviços Públicos ainda são incipientes no Brasil”.

A publicação do presente Dossiê insere-se neste contexto e pretende fomentar uma reflexão sobre as possibilidades e as dificuldades existentes no estudo dos Serviços Públicos. Acreditamos que uma das dificuldades reside na imprecisão dos limites entre as Políticas Públicas e os Serviços Públicos. A priori, ambos se complementam e são interdependentes, no entanto, a dinâmica das suas relações é complexa. A eficiência das Políticas Públicas implantadas por um determinado governo depende em parte da estrutura organizacional dos Serviços Públicos e da capacidade desta estrutura se reformular e absorver novas demandas. E, no sentido inverso, a qualidade de um Serviço Público pode ser ampliada ou reduzida a partir de prioridades definidas pela agenda das Políticas Públicas.

Outro tipo de dificuldade encontrada pelos que exploram a organização e funcionamento dos Serviços Públicos diz respeito às relações entre a sociedade civil o governo. Para além da tradicional representação política partidária, a 


\section{Revista Brasileira de História \& Ciências Sociais - RBHCS}

Vol. 9 No $^{\circ}$ 18, Julho - Dezembro de 2017

sociedade civil desenvolveu um amplo conjunto de práticas através das quais busca influenciar nas decisões e ações do governo. E, as instituições governamentais, por sua vez, se encontram em constante interação com a sociedade civil. Nesta interação, as instituições governamentais podem incorporar ou refutar demandas e críticas procedentes do coletivo social e, ao mesmo tempo, podem modificar o modus operandi sob a influência de alterações na conjuntura econômica e política.

Sem a pretensão de explorar todas as dificuldades existentes no campo das pesquisas sobre os Serviços Públicos, consideramos ser pertinente incluir nesta breve reflexão, o problema do financiamento dos Serviços Públicos problema relevante no contexto de uma crise sem precedente nas finanças públicas brasileiras. Como sabemos, a crise nas finanças públicas é geralmente dimensionada pelo desequilíbrio entre as receitas públicas e as despesas da União Federal, dos Estados e Municípios. No caso do Brasil, parte deste desequilíbrio pode ser atribuída à corrupção que existe dentro e fora do governo. Outra parte diz respeito à disparidade na distribuição dos recursos entre os entes da federação, aos erros na definição de prioridades para os investimentos públicos, ao constante endividamento dos órgãos públicos, à ineficiência dos gestores públicos e à retração nos índices de consumo. De forma direta ou indireta, estes fatores influenciam na oferta e qualidade dos Serviços Públicos e, consequentemente, também demandam uma atenção especial dos historiadores e Cientistas Sociais.

Cientes das dificuldades existentes na interpretação acadêmica dos Serviços Públicos, a RBHCS apresenta aos seus leitores um conjunto de oito artigos que formam o Dossiê História dos Serviços Públicos. Os três primeiros são procedentes do exterior: Alejandra Laura Salomón contribuiu com um estudo sobre as relações entre a política viária e as condições de vida nas áreas rurais da Província de Buenos Aires, no período de 1940 e 1950. Juan Manuel Mátes-Barco abordou o desenvolvimento do serviço público de abastecimento de água na Espanha dos séculos XIX e XX e explorou a convergência de interesses públicos e privados no respectivo serviço. Gloria Paterna Sánchez e Felipe Morente Mejías participam do Dossiê com um artigo sobre o papel do Terceiro Setor no contexto da crise econômica espanhola. Fácil é perceber que os temas procedentes do exterior são distintos e, ao mesmo 


\section{Revista Brasileira de História \& Ciências Sociais - RBHCS}

Vol. $9 \mathrm{~N}^{\mathrm{O}}$ 18, Julho - Dezembro de 2017

tempo, relevantes para os leitores interessados na dinâmica das relações entre a sociedade civil e o governo.

Os autores brasileiros estão representados no Dossiê por cinco artigos: Marcia Cristina Ribeiro Gonçalves Nunes contribuiu com um texto sobre as intervenções urbanísticas que resultaram na criação do Boulevard da República, na cidade de Belém (PA). José Carlos da Silva Cardozo escreveu sobre as transformações ocorridas no Juízo dos Órfãos e destacou a crescente importância que esta instituição recebeu na cidade de Porto Alegre, no final do século XIX. Mario Luis Grangeia mostra o progressivo fortalecimento do Ministério Público Federal a partir da Constituição de 1988, observando empiricamente os Grupos de Trabalho Educação e Saúde para discutir sobre as possibilidades e limites do MP brasileiro, suas continuidades e mudanças na área não penal.

Ana Lucia Britto e Suyá Quintslr colaboraram com um estudo sobre o desenvolvimento das redes de abastecimento de água na Região Metropolitana do Rio de Janeiro. Completando o Dossiê, o artigo escrito por Fabiano Quadros Rückert e Felipe Maropo aborda as experiências de municipalização do abastecimento de água ocorridas nas cidades de Pelotas e Porto Alegre (RS) no período da Primeira República. No conjunto, os autores brasileiros apresentaram importantes contribuições, sobretudo se considerarmos que a História dos Serviços Públicos não pode ser construída sem pesquisas que explorem variáveis como o impacto das obras públicas no espaço urbano, o funcionamento das instituições governamentais, a gradual ampliação de um determinado serviço e as negociações entre o poder público e o setor privado.

Ao final, somente podemos desejar uma ótima leitura e o incentivo para novas pesquisas.

Corumbá/MS; Santa Vitória do Palmar/RS, dezembro de 2017.

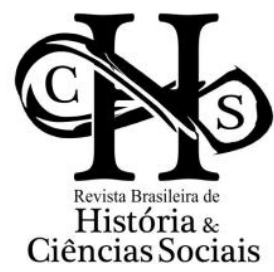

